\title{
RELEVANCE OF BUSINESS TRANSFERS AS A FUNDAMENTAL PILLAR OF RESILIENT ECONOMIES AND OUTLINE OF CURRENT DEVELOPMENT BASED ON A RECENT SURVEY
}

\author{
Max HOGEFORSTER*, Svea HORN \\ Baltic Sea Academy, Blankeneser Landstrasse 7, 22587 Hamburg, Germany
}

Received 12 March 2021; accepted 01 April 2021

\begin{abstract}
Purpose - the article shows the current state of the literature regarding business transfers presents the findings of a survey based on it, that can support the transfer process in the future.

Research methodology - the article is based on three research methods: (a) desk research, (b) surveys and (c) economic analysis. The three methods are highly interdependent.

Findings - the authors conclude that according to literature a lack of appropriate support and services for businesses going through a transfer exist. The survey highlights the challenges and demands that differ quite strongly between old and new member states.

Research limitations - the number from the 283 participants who stated that they had already been involved in business transfers is above average and cannot be extrapolated to all companies.

Practical implications - the practical implications of the study are highly relevant for decision-makers who want to create a structured approach to a sustainable support for business transfers in their countries,

Originality/Value - the article is of high practical relevance. With regards to the evaluation of existing literature, there is a lack of current overviews like this one. The results of the current survey are of particularly importance for the practice of business transfers and their intensive support.
\end{abstract}

Keywords: business transfers, ownership, successor, entrepreneurship.

JEL Classification: M20, M21.

Conference topic: Business Processes: Development, Digitalization, Social Responsibility.

\section{Introduction}

Business transfers have increasingly gained importance over the last three decades, not only within the realm of academic research, but also within national and international policy arenas. For the purpose of this article, business transfers are understood in a broad sense, as defined by the European Commission: "Business transfers refer to the process where all assets representing in their totality an enterprise as a going concern are transferred to a new owner" (Calogirou et al., 2010). As company owners are increasingly reaching retirement age in line with demographic trends in Europe, the issue of transferring the company is essential. While business start-ups have been heavily researched, the importance of business transfers has gone relatively unexplored until more recently. Some scholars even argue that support of successful business transfers may be even more important for stable and sustainable economic growth than those of start-ups (Van Teeffelen, 2012). This is due to the significantly higher survival, turnover and profit rates of transferred businesses compared to start-ups, estimated between $35-50 \%$ for start-ups compared to over $90 \%$ for transferred businesses (Alpeza et al., 2018; Battisti \& Williamson, 2015; Varamäki et al., 2014; Viljamaa et al., 2015a).

The European Commission started paying attention to business transfers in 1994 and has been issuing recommendations and guidelines both for its member states' governments and small and medium size enterprises (SMEs), in general ever since (Alpeza et al., 2018; Bastié et al., 2018; Deschamps et al., 2020). Particularly in the face of a failure rate of just over $30 \%$, it is vital for national governments to provide the best possible support for business transfers in the best possible economic and political environment (European Commission, 2013 in Deschamps et al., 2020).

\footnotetext{
*E-mail: mhogeforster@baltic-sea-academy.eu

(C) 2021 Authors. Published by Vilnius Gediminas Technical University. This is an open-access article distributed under the terms of the Creative Commons Attribution (http://creativecommons.org/licenses/by/4.0/) License, which permits unrestricted use, distribution, and reproduction in any medium, provided the original author and source are credited.
} 
Moreover, the importance of business transfers is expected to increase over the next decade or so, due to the ageing populations of most European countries (Battisti \& Williamson, 2015; Deschamps et al., 2020; Ryan \& Power, 2012; Viljamaa et al., 2015b). Business transfers are particularly important for SMEs as they make up the vast majority of firms across Europe with nearly $98.7 \%$ of all firms being "classified as small firm" (Ryan \& Power, 2012). They thus employ 50.4\% of the overall workforce (approx. 90 million people) and are responsible for nearly $€ 4$ trillion in added value (Alpeza et al., 2018). According to the European Commission (2013, in Deschamps et al., 2020), each year more than 450,000 SMEs and over two million jobs are affected by business transfers. This is particularly concerning, as one third of these business transfers fail due to a variety of reasons, often related to a lack of resources, and are thus endangering up to 150,000 businesses and threatening the loss of 600,000 jobs (Alpeza et al., 2018; Deschamps et al., 2020). Business transfers, especially transfers of SMEs, are therefore not only of great importance for the individual businesses transferred, but also for the overall economic stability of the European economy (Viljamaa et al., 2015a). A resilient economy heavily relies on successful transfers. This is particularly true in the new EU member states and Russia, where many new companies were founded privately in the context of the transition and the structural changes in the economy at the beginning of the 1990s. Starting their companies in their 30-40ties, their owners are now increasingly at the age when a transfer of business is required.

\section{Literature review}

\subsection{Business transfer theory and models}

Business transfers can be analysed from a number of different perspectives, varying from the actual business transfer process to the services provided to support them to the political and economic environment that these are being carried out in (Van Teeffelen, 2012; Varamäki et al., 2014). Research into business transfers was first introduced in the 1980s and has developed from placing a stark focus on family business transfers, to more general research on business transfer processes (Alpeza et al., 2018; Van Teeffelen, 2012). While there is no consensus about the meaning or definition of business transfers, they are generally defined as the transfer of ownership of a company to another person or legal entity of more than $50 \%$ of the assets or shares, while at the same time "assuring the continued existence and commercial activity of the [company]" (Alpeza et al., 2018). This definition was first introduced by Van Teeffelen in 2010 and has enjoyed great support since (e.g., Deschamps et al., 2020; Alpeza et al., 2018). Transfer models were first introduced in the late 1970s, e.g., by Longecker and Schoen in 1978 which, while providing a seven-step process for business transfers, failed to include "any reference to post-succession issues" (Meijaard et al., 2005), an issue that has been repeatedly criticised within other business transfer models as well (Meijaard et al., 2005). A business model developed by Van Teeffelen's highlights the great amount of preparation which needs to go into a business transfer (Bastié et al., 2018; Meijaard et al., 2005; Varamäki et al., 2014). Business owners have a wide variety of different options of how to transfer their business, ranging from transfer to a family member, to transfer to an employee to transfer to an external buyer (Battisti \& Williamson, 2015; Meijaard et al., 2005; Molly et al., 2010; Ryan \& Power, 2012). The success rate of business transfers is also highly dependent on the socio-economic environment in which they take place. This environment, the so-called "business transfer ecosystem", the system in which business transfers take plays, needs to be able to provide transparent, affordable and readily accessible services to business owners seeking to transfer their business (Alpeza et al., 2018; Viljamaa et al., 2015a, 2015b).

While sellers and buyers are understood to represent the main actors in business transfers, the transfer is always influenced by external and internal factors, such as the quality and expertise of advisors, the accessibility of financial institutions and services, as well as market and economic conditions (Van Teeffelen, 2012). Particularly influential are advising parties to the process, as business owners usually lack the necessary expertise for a business transfer which makes a well-working business transfer ecosystem so important (Alpeza et al., 2018). Unfortunately, research has shown that governments and policymakers are generally unaware of the importance of such an ecosystem, and thus still do not offer businesses the necessary support. Another issue is that the services and support offered, as well as the overall economic and political conditions, differ immensely between countries and regions despite the EU's continuous work to support all of its member states with building and expanding their national support structures (Alpeza et al., 2018; Van Teeffelen, 2012; Viljamaa et al., 2015b).

\subsection{Challenges to business transfers}

Although business transfers may seem like a rather straight-forward process at first, business owners who are looking to transfer their business for a number of reasons face many challenges during that process. The literature on business transfers provides a lot of reasons and challenges to explain why over a third of business transfers fail (Alpeza et al., 2018; Deschamps et al., 2020, European Commission in Deschamps et al., 2020). The overall consensus is that business transfers primarily fail due to a lack of knowledge and a lack of affordable and accessible resources for business transfers (Alpeza et al., 2018; Battisti \& Williamson, 2015; Van Teeffelen, 2012; Varamäki et al., 2014; Viljamaa et al. 
2015b). The reason for the lack of knowledge and expertise of business owners of business transfers is due to the fact that for most business owners, a business transfer is a "once-in-a-lifetime issue" (Van Teeffelen, 2012). Business transfers require unique knowledge and skills which are neither acquired nor needed during the every-day practice of running a business (Battisti \& Williamson, 2015; Van Teeffelen, 2012; Varamäki et al., 2014; Viljamaa et al., 2015a). Business owners tend not to plan for succession and often postpone the transfer of their business as much as possible, making it difficult to find a suitable successor (Van Teeffelen, 2012; Varamäki et al., 2017). Nonetheless, despite the EU's acknowledgement of business transfers as a matter of great importance, the "the EU market [still] fails to provide adequate professional services and support for small business owners" (Van Teeffelen, 2012). Overall, there appears to be not only a lack of appropriate support and services for businesses going through a business transfer, but also a general lack of awareness of the difficulties and challenges that businesses face (Alpeza et al., 2018; Van Teeffelen, 2012; Viljamaa et al., 2015b) Particularly small businesses struggle to access the necessary support for a successful business transfer (Battisti \& Williamson, 2015; Van Teeffelen, 2012; Varamäki et al., 2014). This is due to a number of factors. For starters, there does not exist one single point of contact for business transfer advice, but rather a wide variety of intermediaries that offer their services to businesses seeking to transfer. This, however, makes it more difficult for smaller businesses to access the appropriate service and support that they require, as costs increase with each service they access. This results in particularly smaller businesses having to rely on one single intermediary, usually an accountant, who is not adequately equipped to assist and support the business in its transfer (Battisti \& Williamson, 2015).

Another barrier for small businesses in particular is their reluctance to trust outsiders, especially when the business is owner-managed and relies on specific, unique expertise which is generally not passed on to outsiders (Battisti \& Williamson, 2015; Meijaard et al., 2005). This is a distinct challenge especially for family-owned businesses. Family businesses and their unique challenges have enjoyed a lot of attention in business transfer research, nevertheless, even though family business transfers are a special situation, they do not provide the majority of all transfers. Because research suggests that the actual transfer process runs more smoothly if the buyer is already familiar with the acquired company, due to the already existing trust and familiarity with the business and between the buyer and the stakeholders, it is so important to offer adequate support for non-family transfer processes (Bastié et al., 2018; Meijaard et al., 2005; Varamäki et al., 2014). Yet, this reluctance to rely on and trust outsiders also has an effect on non-family business transfers. Business owners and managers prefer to rely on (small) accountancy practices which they already have an established relationship with, rather than maybe other better suited and equipped intermediaries who could give better advice. On top of that, they often find themselves rejected due to the lack of value that they can offer to big business brokers, when they do try to access other, bigger intermediaries. Other intermediaries, such as business support organisations, are also rarely equipped to support businesses of any size, but particularly small businesses, in their business transfer process (Battisti \& Williamson, 2015; Van Teeffelen, 2012).

On top of their lack of expertise, suitable business transfer intermediaries are often difficult to find and generally lack transparency as to what services they offer (Varamäki et al., 2014). Few countries currently offer long-term regional or national programmes for business transfers which makes it difficult for small businesses to access the support they need, while bigger, medium-sized businesses, do not have to rely on public services, but can additionally access private sector support (Van Teeffelen, 2012; Varamäki et al., 2014). Another factor that has a stark influence on the chances of a business succeeding in the long run is "how well they manage their knowledge" (Desouza \& Awazu, 2006) which also influences their long term survival. Poor know-ledge management is particularly problematic for external buyers, because - unlike transfers within the family with a longer learning phase - they often have particularly short transition periods (Cadieux, 2007). SMEs especially lack the traditional resources due to their size which gives knowledge and efficient knowledge management even more importance (Desouza \& Awazu, 2006; Durst \& Edvardsson, 2012; Rodrigues et al., 2014). Knowledge and knowledge management also play a role when it comes to gaining access to business transfer intermediaries and potential buyers. They also become an issue during business transfers, as SMEs generally lack explicit knowledge management systems and instead often rely on the owner-manager and their expertise and the informal transfer of information within an enterprise (Centobelli et al., 2017; Desouza \& Awa$\mathrm{zu}, 2006)$. They do not have the resources to adequately manage knowledge in their everyday activities, resulting in knowledge "being kept in the minds of the owner and some key employees" (Durst \& Edvardsson, 2012). Thus, when the owner-manager leaves the business, a vital information also leaves the business. For this reason, making effective knowledge management part of the transfer process is so important (Rodrigues et al., 2014; Durst \& Wilhelm, 2012). Unfortunately, research has shown that businesses often underestimate knowledge management as part of the transfer process and therefore run into big issues caused by knowledge gaps after a business transfer (Thévenard-Puthod, 2020). A serious challenge for all companies continues to be the lack of skilled workers. This inevitably also has an impact on the number of potential entrepreneurs who are suitable to continue a company at all. In particular in Russia and the Eastern member states it is not easy to find a suitable successor. It is precisely in these countries that it is particularly difficult to find suitable successors. Almost all countries suffer from demographic change, so that there are generally not enough young people. But Estonia, Latvia, Lithuania and Poland in particular have lost additional potential young entrepreneurs as part of the so-called brain drain (Kaczmarczyk \& Okólski, 2008). Of course, this has 
an immense economic impact and there are efforts to bring back the young people who have left (Svazas \& Liberyte, 2019), but with moderate success. An indispensable prerequisite for the successful continuation of the companies is, of course, not only the quantitative component of young people as potential takeovers, but also their qualifications. Therefore, they need an entrepreneurial education that is very practice-oriented and enables them to continue running a business. Vocational training or studies in the dual model, so-called work-based learning, seem to be predestined for this (Hogeforster \& Alexander, 2018). An essential prerequisite for any successful business transfer in companies and it must be emphasised that a large number of transfers unfortunately fail and thus endanger jobs - is of course successful negotiation between owner and successor (Matalamäki et al., 2020).

\subsection{Literature review conclusion}

Overall, there appears to be not only a lack of appropriate support and services for businesses going through a business transfer, but also a general lack of awareness of the difficulties and challenges that businesses face (Alpeza et al., 2018; Van Teeffelene, 2012; Viljamaa et al., 2015b). There thus needs to be more awareness-building activities among policymakers, intermediaries and business owners on the challenges arising during business transfers and the support available. Additionally, the transfer ecosystem needs to be expanded and altered to offer the necessary longterm support not just for bigger and medium-sized companies, but particularly to small businesses which suffer the most under business transfer failures.

\section{Results of survey}

Since the topic of age-related company changes has only been sparsely researched to date, the authors initiated a new study. From October 2020 until March 2021 a survey has been conducted by the authors to learn more about the status quo, challenges and needs for support when it comes to business transfers. 283 participants from 14 countries, mainly around the Baltic Sea Region, took part in the survey. The survey was distributed through a network of 76 chambers of commerce, universities and public administration around the Eastern region. The settings were such that only one response option was allowed from each IP. A total of 12-16 questions were asked, following a piped logic depending on previous answers. In case of multiple answer options, the order of answers was randomised in each questionnaire. To minimise the language barrier of SMEs, it was available in English, German, Estonian, Latvian, Lithuanian, Polish, Russian and Swedish language. In this way, a relatively high number of very small companies could be achieved, which have fewer than 10 employees and do not have much time to fill out surveys in their dayto-day business. The average time for responses was 6 minutes. In the beginning, the participants were asked which organisation are relevant when promoting business transfers. Rather unusual was the questions regarding the support by knowledge institutions. But in particular organisations like business schools and universities can play an essential role for a strong ecosystem when cooperating with companies (Mazzarol et al., 2016), in particular when it comes to an innovative entrepreneurial education (Hogeforster \& Priedulena, 2014). Thus, this option was included and surprisingly slightly more education institutions answered than intermediaries. Overall, with 140 filled questionnaires the most responses were collected by small company with less than 10 employees $(49.47 \%)$, which is shown in Table 1 .

Table 1. Participants of the survey (source: formed by the authors)

\begin{tabular}{|l|c|c|}
\hline & Number of answers & Percentage \\
\hline Private sector (small company, less than 10 employees) & 140 & $49.47 \%$ \\
\hline Private sector (medium-sized company, less than 250 employees) & 61 & $21.55 \%$ \\
\hline Private sector (large company, more than 250 employees) & 14 & $4.95 \%$ \\
\hline Intermediary (Chambers, Business support organisations) & 28 & $9.89 \%$ \\
\hline Education (VET school, University) & 29 & $10.25 \%$ \\
\hline Public (Ministries, Authority, National Agency, Policy Maker) & 9 & $3.18 \%$ \\
\hline Other & 2 & $0.71 \%$ \\
\hline Total & 283 & $100 \%$ \\
\hline
\end{tabular}

\subsection{Current challenges}

At the beginning, the participants of the survey were asked what the biggest challenge for their companies will be in the next two years. They answered on a scale of $1-5$, with 1 meaning no challenge at all and 5 indicating a major challenge. In order to present a comparability and the significance of company transfers, challenges were selected 
which are known to pose challenges to SMEs in recent years (Eggers, 2020; Hogeforster, 2014; Uvarova \& Vitola, 2019). For this purpose, the Corona crisis was added due to recent circumstances. Also some research argues that the impact of the corona virus on European SMEs is not as strong as often assumed (Secinaro et al., 2020) it is assessed as a strong threat on a subjective level. This is confirmed by the presented survey as shown in Table 2. Overall, the Corona Virus is clearly the dominant threat for the participants, with $72.34 \%$ of all participants rating this with 4 (big challenge) or the highest possible score 5 (major challenge), followed by cash flow Interestingly, the generation shift in companies is considered the third biggest challenge and has been mentioned more times than the often-mentioned digitalisation, qualification and innovation challenges. This may be due to the fact that the entire survey was very much concerned with business transfers and specifically addressed companies affected by them.

Table 2. Challenges (source: formed by the authors)

\begin{tabular}{|l|c|c|c|c|c|c|}
\hline & $\begin{array}{c}1 \text { no } \\
\text { challenge }\end{array}$ & $\begin{array}{c}2 \text { small } \\
\text { challenge }\end{array}$ & $\begin{array}{c}\text { S somehow a } \\
\text { challenge }\end{array}$ & $\begin{array}{c}4 \text { big } \\
\text { challenge }\end{array}$ & $\begin{array}{c}5 \text { major } \\
\text { challenge }\end{array}$ & Average \\
\hline Low education level of staff & $\begin{array}{c}32.86 \% \\
92\end{array}$ & $\begin{array}{c}27.86 \% \\
78\end{array}$ & $\begin{array}{c}23.57 \% \\
66\end{array}$ & $\begin{array}{c}12.50 \% \\
35\end{array}$ & $\begin{array}{c}3.21 \% \\
9\end{array}$ & 2.25 \\
\hline Missing Qualification of managers & $\begin{array}{c}22.14 \% \\
62\end{array}$ & $\begin{array}{c}28.93 \% \\
81\end{array}$ & $\begin{array}{c}31.07 \% \\
87\end{array}$ & $\begin{array}{c}15.36 \% \\
43\end{array}$ & $\begin{array}{c}2.50 \% \\
7\end{array}$ & 2.47 \\
\hline Innovation level & $\begin{array}{c}16.43 \% \\
46\end{array}$ & $\begin{array}{c}30.36 \% \\
85\end{array}$ & $\begin{array}{c}36.07 \% \\
101\end{array}$ & $\begin{array}{c}14.64 \% \\
41\end{array}$ & $\begin{array}{c}2.50 \% \\
7\end{array}$ & 2.56 \\
\hline Digitalisation level & $\begin{array}{c}21.43 \% \\
60\end{array}$ & $\begin{array}{c}23.93 \% \\
67\end{array}$ & $\begin{array}{c}28.93 \% \\
81\end{array}$ & $\begin{array}{c}19.29 \% \\
54\end{array}$ & $\begin{array}{c}6.43 \% \\
18\end{array}$ & 2.65 \\
\hline Lack of workforce & $\begin{array}{c}30.71 \% \\
86\end{array}$ & $\begin{array}{c}18.93 \% \\
53\end{array}$ & $\begin{array}{c}16.07 \% \\
45\end{array}$ & $\begin{array}{c}16.43 \% \\
46\end{array}$ & $\begin{array}{c}17.86 \% \\
50\end{array}$ & 2.72 \\
\hline Generation shift in companies & $\begin{array}{c}16.01 \% \\
45\end{array}$ & $\begin{array}{c}15.30 \% \\
43\end{array}$ & $\begin{array}{c}25.98 \% \\
73\end{array}$ & $\begin{array}{c}34.52 \% \\
97\end{array}$ & $\begin{array}{c}8.19 \% \\
23\end{array}$ & 3.04 \\
\hline Cash flow & $6.81 \%$ & $19.71 \%$ & $28.67 \%$ & $18.64 \%$ & $26.16 \%$ & 73 \\
\hline Pandemic / Corona Situation & $2.13 \%$ & $10.99 \%$ & $14.54 \%$ & $37.59 \%$ & $34.75 \%$ & 3.38 \\
\hline
\end{tabular}

There is a notable difference when the results are divided into two groups of countries. The old member states and the new member states (Estonia, Hungary Latvia, Lithuania, Poland) as well as Russia and Belarus, hereafter referred to as Group 1. Like shown in Figure 1. Here the concerns regarding the Corona virus (average rating 4.11) and cash flow (average rating 3.81) are clearly dominant. Third is the generation shift in companies (average rating 2.73). The lack of workforce is considered to be a small challenge only (average rating 1.97).

In the old member states like Denmark, Finland, France, Germany, Netherlands, Sweden and Norway, hereafter referred to as Group 2 the priorities are very different, as shown in Figure 2. The lack of available workforce is by far the most pressing challenge, with an average rating of 4.18. Followed by generation shift with a rating of 3.63 and the Corona pandemic with 3.56. Considered to be the least pressing challenge at the moment seems to be innovation level, that is rated with 2.45 .

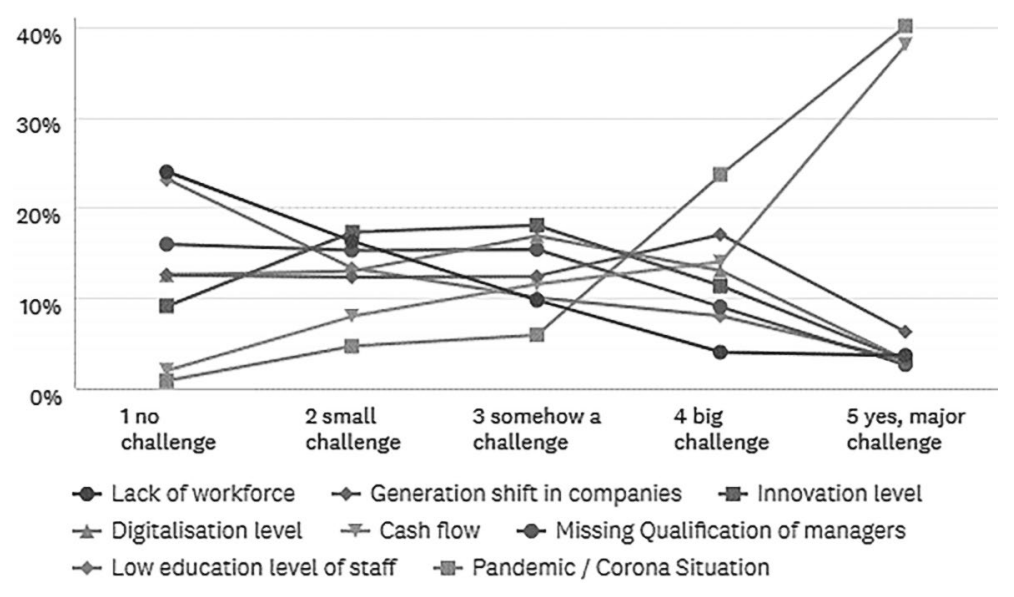

Figure 1. Challenges of new member states (Group 1) (source: formed by the authors) 


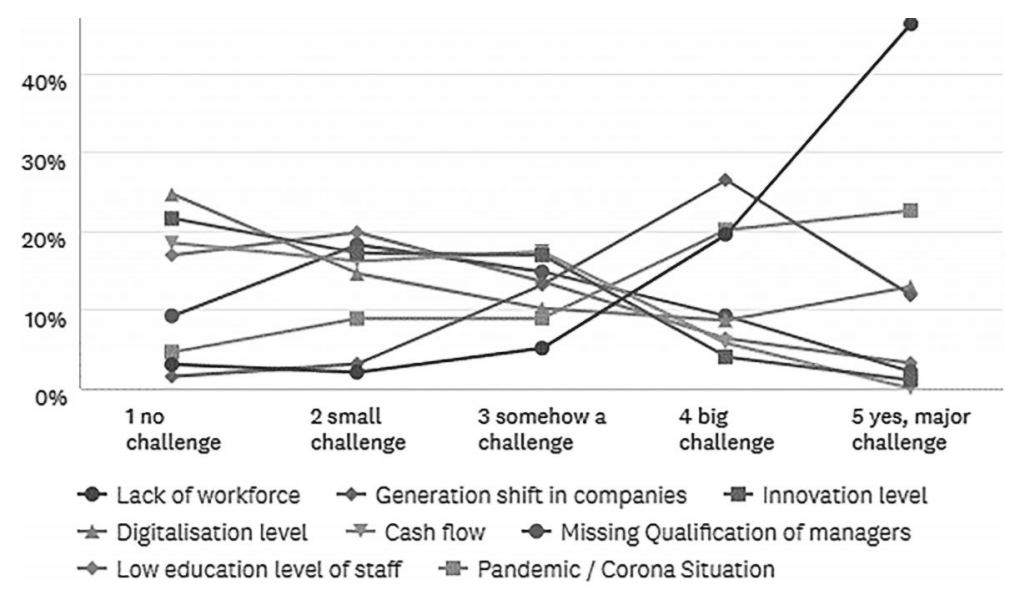

Figure 2. Challenges old member states (Group 2) (source: formed by the authors)

Consequently, labour shortages are the most important problem in the old member states and hardly play a role in the new member states at present. It can be said that these are all very relevant issues, and innovation, digitalisation and skills are undoubtedly still important for the firms. However, the fact that the change of company is in the middle of this selection of all important topics confirms its high relevance.

\subsection{Experiences}

The participants were asked about their experiences with business transfers. $20.36 \%$ had already been involved in a handover, mainly as advisors or successors, as a follow-up question clarified. 9.29\%, corresponding to 26 participants, declared themselves to be in the handover process. $32.50 \%$ expect to be involved in a handover in the future and only $37.86 \%$ answered that this is not relevant for them at present. Conversely, this means that $62.14 \%$ of the respondents have already been involved in a transfer process or are currently involved. This is an extraordinarily high number and may be due to the fact that the survey clearly deals with the topic and cannot be extrapolated for the European economy in general. However, the number of companies to be transferred is still very high overall. For Germany, it is expected that 76,000 SMEs will have to be handed over to the new generation in 2020 and 2021 respectively (Schwartz, 2019). An interesting result came from a follow-up question for those who are currently in a handover process. 13 companies or $50 \%$ answered that they are already receiving external support. 2 companies, corresponding to $7.69 \%$, said they did not want any support and were doing everything internally. 11 participants or $42.31 \%$ said they would like to receive support. This clearly shows that there is a demand for support.

\subsection{Support}

The participants, who have yet not been part of a transfer, were asked what kind of support they needed. needs they personally expect in the context of a handover. Since the results in this question diverge strongly by country, two country groups are again combined: The new member states and Russia/Belarus (Group 1) and the old member states with Norway (Group 2). The choices were "business consultation, entrepreneurial training, financial consultation, improved business support network and support in finding a successor". From Group 1 a total of 147 participants answered. Like shown in Figure 3, in the countries of Group 1 there is a strong need for financial consultation with $58.50 \%$ of all answers and business consultation with $57.14 \%$ of all answers. Support to find a successor is only seen relevant by $21.77 \%$.

For the Group 2 the picture is quite different, like shown in Figure 4. A total of 47 participants from these countries answered. With $82.89 \%$ the strongest need is very clearly the need to find a successor for the company, so the need for a matchmaking between the retiring owner and the potential successor. Improved business networks are rated second with $34.04 \%$. A need for financial consultations is hardly in demand with only $14.89 \%$ of all answers, showing that these participants seem to be quite confident regarding the financial part of the transfer process.

It is noteworthy that the differences between the two groups of countries on this issue are also serious and in part diametrical.

\subsection{Duration}

Another crucial element for the success of a transfer is the duration of a business transfer. In the literature mentioned above and from practical experience, it is known that the planning horizon of SMEs is generally short. Planning is 
initially done for the coming months. Strategic planning, as in larger companies, is generally less prevalent in SMEs due to the demands of day-to-day business (Stonehouse \& Pemberton, 2002). As shown in Figure 5, those participants who already have experience or are in a handover process assume that this will take an average of 12-24 months.

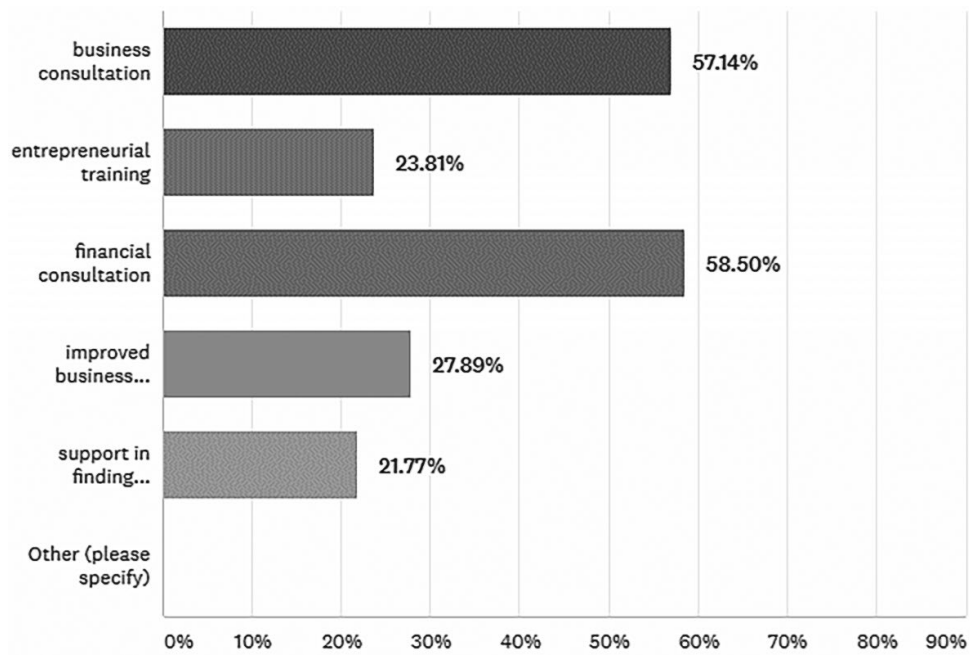

Figure 3. Support for transfer, new member states (Group 1) (source: formed by the authors)

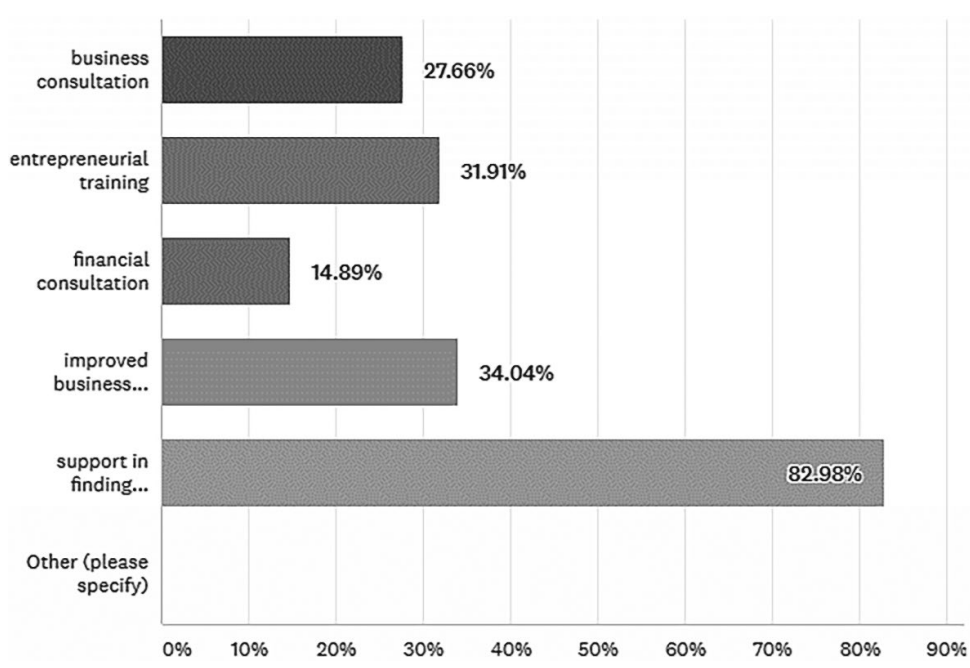

Figure 4. Support for a transfer, old member states Group 2) (source: formed by the authors)

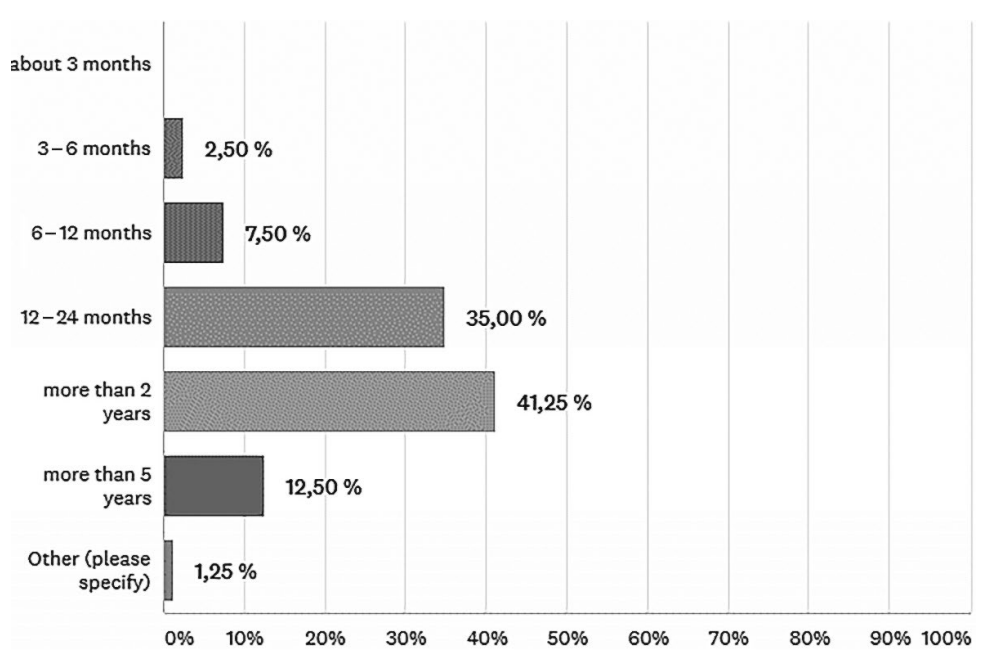

Figure 5. Duration of transfer, answered by experienced participants (source: formed by the authors) 
Overall, only very few (10\%) assume that a handover will take between 3 and 6 months. The vast majority of $88.75 \%$ estimate the duration of the handover to be between 12 and 60 months. The data divided by size of companies indicated further that the duration increases depending on the size of the company, i.e., in a small company the handover process can already be completed after 12 months, but in a large medium-sized company it is actually planned for 4 years. The other group of participants that consider a transfer maybe in the future or not at all expect that this process takes less time, with $18.51 \%$ of participants even only between 3-6 months like shown in Figure 6 .

A transition period of about 3 months is usually too short, unless the company is simply bought out by a competitor, which is not a transition in the true sense of the word. When the company passes from one generation to the next, this is accompanied by significant organisational upheaval and poses major challenges for both management and employees and, where applicable, suppliers (DeTienne, 2010; Haveman et al., 2004). This shows that especially companies that have not yet dealt with the generation change need external support here and at least get the awareness to consider a longer planning phase.

\subsection{Support}

Finally, the participants were asked which organisations in their countries were particularly suitable for supporting a business transfer. There were several possible answers. The choices were "business support organisations (chambers), regional development agencies (public), Financial institutions, Knowledge institutions or private consultants". Again, the results between the different countries involved are so different, that a separate analysis was made for Group 1 and Group 2. As shown in Figure 7 the new member states believe in a majority if 55\% that private business consultations can provide the best support.

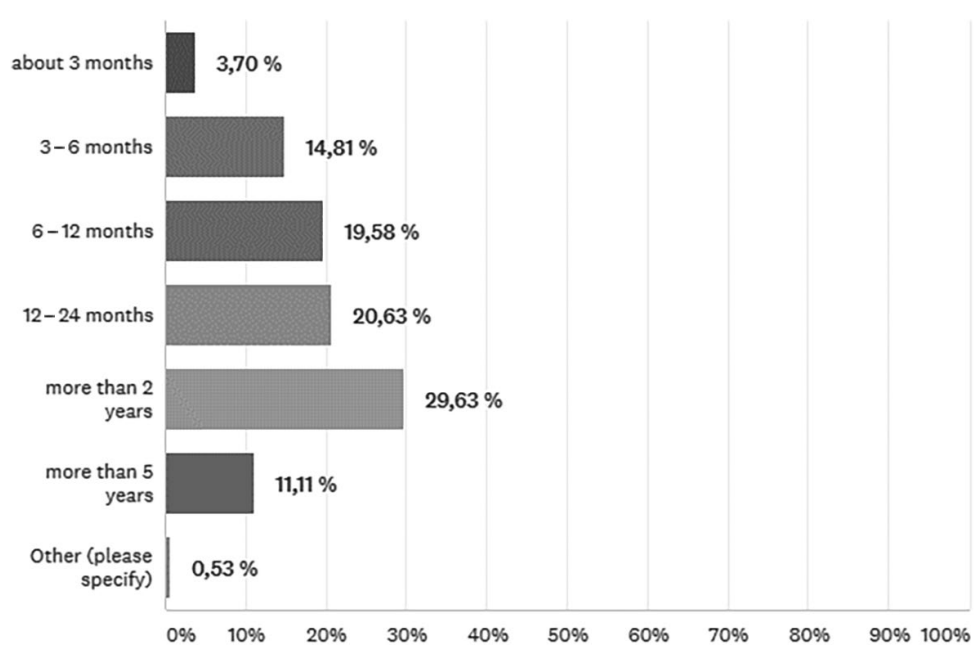

Figure 6. Duration estimates by inexperienced participants (source: formed by the authors)

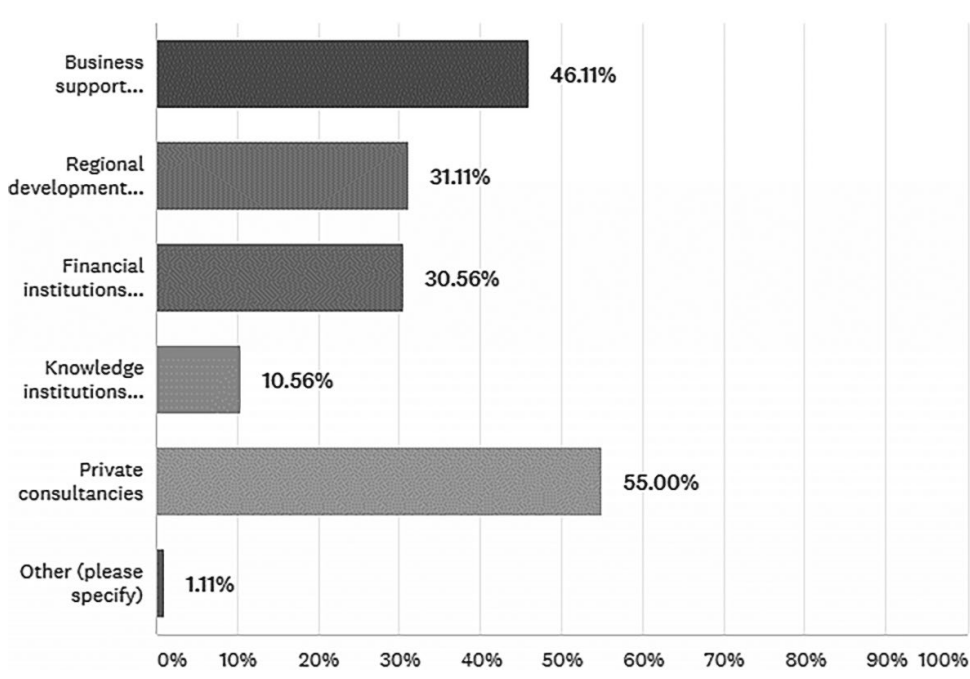

Figure 7. Who can support business transfers, new member states and RU/BY (Group 1) (source: formed by the authors) 


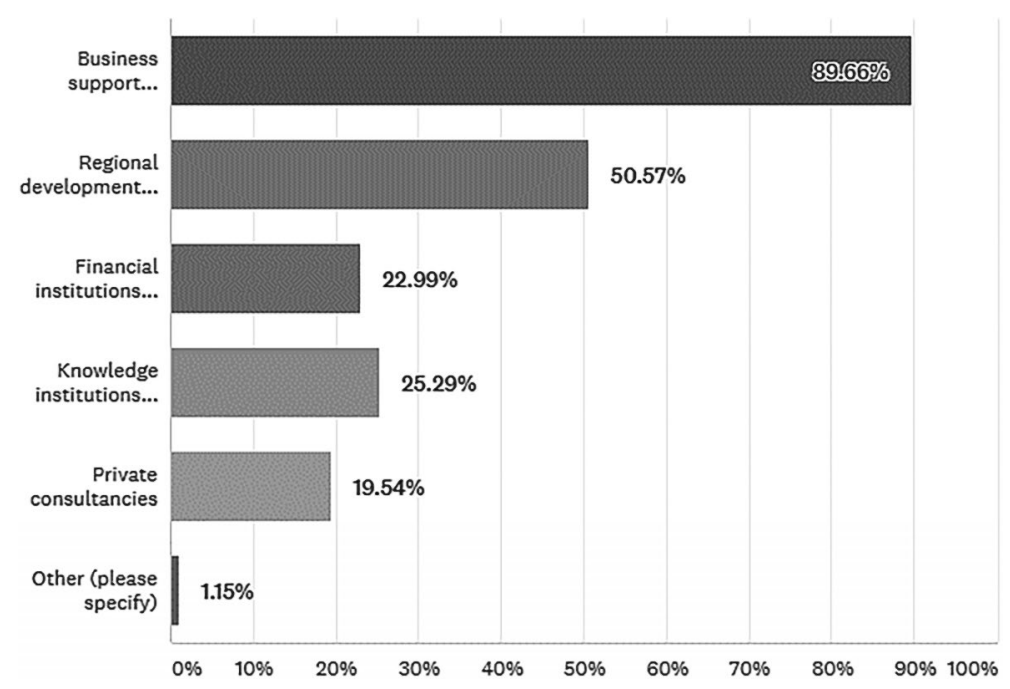

Figure 8. Who can support business transfers, old member states and NOR (Group 2) (source: formed by the authors)

In the old member states, the role of business support organisations such as chambers of commerce is very much appreciated, with $89.66 \%$ like shown in Figure 8. Indeed, they have their own departments and experts to support their member companies during the handover in most old member states. Secondly, the regional development agencies are indicated, and the private consultants seem to be less in demand.

Both groups consider knowledge institutions less relevant as organisations that can support their transfer process. This was mainly indicated by larger companies. The difference in the perception of business support organisations such as chambers is striking. This may be due to the fact that in old member states such as France, Austria, Belgium or Germany, the chambers of commerce are very strong and often have semi-public structures. These chambers have been performing sovereign tasks for a long time. The chambers in Lithuania, Latvia, Estonia or Poland on the other hand, are organised much more privately and compete more strongly with the consultancy market. The fact that chambers in the new member states do not have compulsory membership forces them more to compete on the free market for services. As handovers will increase strongly in the future, the further qualification of internal advisors to become business transfer experts could be very interesting and actually an advantage. The very consultation of the generation change means that one needs a permanent contact person for years, whom one trusts sufficiently. SMEs need to plan early for the upcoming transfer and should allow at least 2 years. It can also be the task of the chambers of commerce, regional development agencies and business consultants to establish this as a future and permanent field of consultation.

\section{Conclusions}

The literature review revealed that, despite its enormous economic importance, research has largely ignored the area of business transfer over the last 20 years. Much of the existing articles refer to business succession within the family and ignore other forms. A successful generation shift in SMEs is of utmost importance for a resilient economy. Especially in SMEs, the individual process is very different and requires targeted counselling. Relevant advisory fields during the transfer, such as knowledge management, are often overlooked. The current survey clearly shows that the topic is of great importance for SMEs, but that the challenges and demand for support diverge between the old and the new member states. The latter are in particular need of help in finding suitable successors, while in the new Member States financial and entrepreneurial advice is particularly required. SMEs need to plan early for the upcoming transfer and should allow at least 2 years. It can also be the task of the chambers of commerce and similar business support organisation in the new member states to establish this as a future and permanent field of consultation.

\section{Disclosure statement}

The authors do not have any competing financial, professional, or personal interests from other parties. 
M. Hogeforster, S. Horn. 2021. Relevance of business transfers as a fundamental pillar of resilient economies and outline of current development based on a recent survey

\section{References}

Alpeza, J., Tall, P., \& Mezulić Juric, P. (2018). The challenges of SME business transfers: The evidence from Croatia and Finland. Organizacija, 51(2), 135-145. https://doi.org/10.2478/orga-2018-0012

Bastié, F., Cieply, S., \& Cussy, P. (2017). Does mode of transfer matter for business performance? Transfers to employees versus transfers to outsiders. Small Business Economics, 50, 77-89. https://doi.org/10.1007/s11187-017-9903-5

Battisti, M., \& Williamson, A. J. (2015). The role of intermediaries in the small business transfer process. Small Enterprise Research, 22(1), 32-48. https://doi.org/10.1080/13215906.2015.1022129

Cadieux, L. (2007). Succession in small and medium-Sized family businesses: Toward a typology of predecessor roles during and after instatement of the successor. Family Business Review, 20(2), 95-109. https://doi.org/10.1111/j.1741-6248.2007.00089.x

Calogirou, C., Fragozidis, K., Houdard-Duval, E., \& Perrin-Boulonne, H. (2010). Business dynamics: Start-ups, business transfers and bankruptcy. PLANET S.A., CCIP, DTI and GFA. Brussels: European Commission, DG Enterprise and Industry. https:// docplayer.net/12092095-Business-dynamics-start-ups-business-transfers-and-bankruptcy.html

Centobelli, P., Cerchione, R., \& Esposito, E. (2017). Knowledge management systems: The hallmark of SMEs. Knowledge Management Research \& Practice, 15(2), 294-304. https://doi.org/10.1057/s41275-017-0054-x

Deschamps, B., Missonier, A., Thévenard-Puthod, C., Robic, P., \& Barbelivien, D. (2020). Business transfers, family firms and entrepreneurship ( $1^{\text {st }}$ ed.). Routledge. https://doi.org/10.4324/9781003022527

Desouza, K. C., \& Awazu, Y. (2006). Knowledge management at SMEs: Five peculiarities. Journal of Knowledge Management, 10(1), 32-43. https://doi.org/10.1108/13673270610650085

DeTienne, D. R. (2010). Entrepreneurial exit as a critical component of the entrepreneurial process: Theoretical development. Journal of Business Venturing, 25(2), 203-215. https://doi.org/10.1016/j.jbusvent.2008.05.004

Durst, S., \& Wilhelm, S. (2012). Knowledge management and succession planning in SMEs. Journal of Knowledge Management, 16(4), 637-649 https://doi.org/10.1108/13673271211246194

Durst, S., \& Edvardsson, I. R. (2012). Knowledge management in SMEs: A literature review. Journal of Knowledge Management, 16(6), 879-903. https://doi.org/10.1108/13673271211276173

Eggers, F. (2020). Masters of disasters? Challenges and opportunities for SMEs in times of crisis. Journal of Business Research, 116, 199-208. https://doi.org/10.1016/j.jbusres.2020.05.025

Haveman, H. A., Khaire, M., \& Khaire, M. V. (2004). Survival beyond succession? The contingent impact of founder succession on organizational failure. Journal of Business Venturing, 19(3), 437-463. https://doi.org/10.1016/S0883-9026(03)00039-9

Hogeforster, M. (2014). Future challenges for innovations in SMEs in the Baltic Sea Region. Procedia - Social and Behavioral Sciences, 110, 241-250. https://doi.org/10.1016/j.sbspro.2013.12.867

Hogeforster, M., \& Alexander, M. (2018, May 3-4). Dual training schemes promotion entrepreneurship and business transfers experiences from Lithuania. In $10^{\text {th }}$ International Scientific Conference "Business and Management 2018”. Vilnius, Lithuania. https://doi.org/10.3846/bm.2018.43

Hogeforster, M., \& Priedulena, E. (2014). The significance and impact of innovation networks of academia and business with a special emphasis on work-based learning. Baltic Journal of European Studies, 4(2), 69-82. https://doi.org/10.2478/bjes-2014-0016

Kaczmarczyk, P., \& Okólski, M. (2008). Economic impacts of migration on Poland and the Baltic states. MobileWelfare-European welfare systems in times of mobility the economic integration of immigrants in a country in the transition phase of the migration cycle-Poland versus selected EU countries (grant no. 2014/ 14/E/HS4/00387). View project. https://www.researchgate. net/publication/253037942

Matalamäki, M., Varamäki, E., Viljamaa, A., Tall, J., \& Mäkelä, A.-M. (2020). Unsuccessful SME business transfers. Journal of Enterprising Culture, 28(2), 121-146. https://doi.org/10.1142/s0218495820500065

Mazzarol, T., Battisti, M., \& Clark, D. (2016). The role of universities as catalysts within entrepreneurial ecosystems. In D. Clark, T. McKeown, \& M. Battisti (Eds.), Rhetoric and reality: Building vibrant and sustainable entrepreneurial ecosystems (pp. 3668). Tilde University Press. https://www.researchgate.net/publication/307925580

Meijaard, J., Uhlaner L., Diephuis, B., Flören, R., \& Sanders, B. (2005). The relationship between successor and planning characteristics and the success of business transfer in Dutch SMEs. SCALES-paper N200505. Zoetermeer, Netherlands. https:// www.researchgate.net/publication/5012701_The_relationship_between_successor_and_planning_characteristics_and_the_success_of_business_transfer_in_Dutch_SMEs

Molly, V., Laveren, E., \& Deloof, M. (2010). Family business succession and its impact on financial structure and performance. Family Business Review, 23(2), 131-147. https://doi.org/10.1177/089448651002300203

Ryan, G., \& Power, B. (2012). Small business transfer decisions: What really matters? Evidence from Ireland and Scotland. Irish Journal of Management, 31(2), 99-125.

Rodrigues, P., Borges, A. P., \& Aleixo, A. (2014). The importance of knowledge management in the succession process of family businesses. In European Conference on Knowledge Management - ECKM 2014 (pp. 826-833). Polytechnic Institute of Santarém, Portugal. https://search.proquest.com/docview/1672880190?pq-origsite=gscholar\&fromopenview=true

Schwartz, M. (2019). Wave of successions in German SMEs. KfW Research. Focus on Economics, No 274.

Secinaro, S., Calandra, D., \& Biancone, P. P. (2020). Reflection on Coronavirus accounting impact on small and medium sized enterprises (SMEs) in Europe. International Journal of Business and Management, 15(7), 48-56. https://doi.org/10.5539/ijbm.v15n7p48

Stonehouse, G., \& Pemberton, J. (2002). Strategic planning in SMEs - some empirical findings. Management Decision, 40(9), 853-861. https://doi.org/10.1108/00251740210441072

Svazas, M., \& Liberyte, M. (2019). Brain drain impact on the economy: Baltic States case. Social \& Economic Revue, 17(1), 66-76. https://fsev.tnuni.sk/revue/papers/227.pdf 
Thévenard-Puthod, C. (2020). How to effectively support external buyers in a post-business transfer situation. In B. Deschamps, A. Missonier, C. Thévenard-Puthod, \& P. Robic (Eds.), Business transfers, family firms and entrepreneurship. Routledge. https://doi.org/10.4324/9781003022527-18

Uvarova, I., \& Vitola, A. (2019). Innovation challenges and opportunities in European rural SMEs. Viešoji politika ir administravimas, 18(1), 152-166. https://doi.org/10.5755/j01.ppaa.18.1.23134

Van Teeffelen, L. Dr. (2012). Avenues to improve success in SME business transfers: Reflections on theories, research and policies. http://www.transeo-association.eu/uploads/Papiers\%20academic/Avenues $\% 20$ to $\% 20 \mathrm{improve} \% 20$ success $\% 20 \mathrm{in} \% 20 \mathrm{SME} \% 20$ business\%20transfers\%20June\%202012.pdf

Varamäki, E., Tall, J., Viljamaa, A., Mäkelä, A. M., \& Matalamäki, M. (2017). Unsuccessful SME business transfers. In N. Delener \& C. Schweickert (Eds.), Changing business environment: Gamechangers, opportunities and risks (pp. 983-990). Global Business and Technology Association, Vienna. https://gbata.org/wp-content/uploads/2017/12/ReadingsBook-GBATA-2017-Final. pdf

Varamäki, E., Viljamaa, A., Tall, J., \& Lansiluoto, A. (2014). The success of SME business transfers - Buyers' and successors' perspective. In Conference: ICSB, 11-14.6.2014. Dublin, Ireland. https://www.researchgate.net/publication/264093855_The_ Success_of_SME_Business_Transfers_-_Buyers'_and_Successors'_Perspective

Viljamaa, A., Tall, J., Varamäki, E., Durst, $\overline{\text { S., }}$ \& Singer, S. (2015a). Introduction: Business transfer ecosystems and awareness raising. In A. Viljamaa, J. Tall, E. Varamäki, S. Singer, \& S. Durst (Eds.), Business transfer ecosystems and awareness raising activities (pp. 5-14). Publication of Seinäjoki University of Applied Sciences. https://www.theseus.fi/bitstream/handle/10024/97257/B108.pdf? sequence=1

Viljamaa, A., Tall, J., Varamäki, E., Singer, S., \& Durst, S. (2015b). Summary and conclusions: Business transfer ecosystems and awareness raising activities in partner countries. In A. Viljamaa, J. Tall, E. Varamäki, S. Singer, \& S. Durst (Eds.), Business transfer ecosystems and awareness raising activities (pp. 112-119). Publication of Seinäjoki University of Applied Sciences. https:/www.theseus.fi/bitstream/handle/10024/97257/B108.pdf?sequence=1 